\title{
Association Between Drinking Water Treatment And Diarrhea Among Under-Five Years Children
}

\author{
Yesvi Zulfiana ${ }^{1}$, Nurul \\ Fatmawati $^{2}$, Siskha Maya \\ Herlina $^{3}$ \\ ${ }^{1}$ Bachelor of Midwifery, Stikes \\ Yarsi Mataram \\ ${ }^{2}$ Bachelor of Midwifery, Stikes \\ Yarsi Mataram \\ ${ }^{3}$ Bachelor of Midwifery, Stikes \\ Yarsi Mataram \\ Email: \\ yesvizulfiana@gmail.com
}

Received : March 14 2021

Accepted : April 16 2021

Published : May 20 2021

\begin{abstract}
Diarrhea is still a health problem in the world, especially in developing countries. The World Health Organization (WHO) explained that the cause of death in infants and toddlers is diarrhea, which ranks second. Meanwhile, based on Indonesia's health profile in 2015, there were 18 outbreaks of diarrhea in 11 provinces, 18 districts / cities, with 1,213 sufferers and 30 deaths (CFR 2.47\%). Several factors related to the incidence of diarrhea are maternal care, birth weight and environmental sanitation. This study aims to determine the relationship between maternal parenting, birth weight and environmental sanitation with the incidence of diarrhea in children under five in Selagalas Village, the working area of Cakranegara Health Center. This study used a cross-sectional quantitative design on 104 toddlers who were selected by systematic random sampling in three selected environments in Selagalas Village. Data were collected by structured interviews using questionnaires and observation sheets. Data analysis was carried out bivariately using logistic regression to see the relationship between family drinking water management and the incidence of diarrhea. $64.42 \%$ of children under five were found to have experienced diarrhea. The variable related to the incidence of diarrhea was the lack of drinking water management with a value of $P=0.03$. The management of family drinking water is still lacking so it is necessary to make health promotion efforts for the family to improve the management of family drinking water that meets the requirements so that it can improve the behavior of a clean and healthy life.
\end{abstract}

Keywords: Diarrhea, drinking water, treatment

This is an open-acces article distributed under the terms of the Creative Commons Attribution-ShareAlike 4.0 International License.

\section{INTRODUCTION}

Until now, diarrhea is still a health problem in the world, especially in developing countries. The World Health Organization (WHO) explained that the cause of death in infants and toddlers is diarrhea, which ranks second (WHO, 2011). Basic Health Research Data (Riskesdas) Balitbangkes in 2007 shows the prevalence of diarrhea in infants $(<1$ year) ranks second after the age of 1-4 years with a percentage of $16.5 \%$. Riskesdas also stated that the most common cause of infant mortality was diarrhea (31.4\%). According to the 2010 diarrhea morbidity survey, the largest proportion of patients under five was the age group 6-11 months, amounting to $21.65 \%$ (Ministry of Health, 2011). 
Recapitulation of the number of diarrhea outbreaks from 2008 to 2015 , it can be seen that the CFR when the outbreak was still high (> 1\%) except in 2011 the CFR when the outbreak was $0.40 \%$, while in 2015 the CFR of diarrhea during outbreaks even increased to 2.47\% (MOH RI, 2015). Meanwhile, based on Indonesia's health profile in 2015, there were 18 outbreaks of diarrhea in 11 provinces, 18 districts / cities, with 1,213 sufferers and 30 deaths (CFR 2.47\%). The mortality rate (CFR) when an outbreak of diarrhea is expected to be <1\% (MOH, 2015).

The negative impact of the high mortality rate caused by diarrhea, namely an impact on the quality of health services, this is the basis used to assess the optimal health status, the lack of handling of health personnel in preventing diarrhea is one of the factors that need to be considered. The impact of diarrhea that occurs in infants in addition to death is dehydration, disruption of growth (failure to thrive) and is the main cause of malnutrition in children under five years (WHO, 2009).

One of the causes of the high rate of diarrhea mortality and morbidity is the lack of public knowledge about efforts to prevent and manage diarrhea. Diarrhea occurs through unclean behavior such as not washing hands before preparing food (Widoyono, 2008). According to Blum, there are four factors that influence public or individual health status, namely behavior, health services, environment and heredity. Behavior as one of the factors affecting health has a big share in influencing health status because behavior can control other factors, namely the environment and health services. The creation of a healthy environment cannot be separated from human behavior. Even though health facilities are adequate, health services will not be successful without changes in people's behavior (Nasution, 2006). This study aims to determine the relationship between family drinking water management and the incidence of diarrhea in children under five.

\section{MATERIALS AND METHODS}

This study used a cross-sectional design and was conducted on 104 respondents who were selected through systematic random sampling in three neighborhoods of Selagalas which were randomly selected from a total of seven neighborhoods. Data were collected by means of interviews using a questionnaire and observation using an observation sheet. The inclusion criteria used were respondents who had children under five.

The data collected by interview were about the incidence of diarrhea, mother characteristics, toddler characteristics, mother knowledge, mother's perception, exclusive breastfeeding, measles immunization, and drinking water management with appropriate indicators of drinking water management. All data were analyzed univariately to see the distribution frequency and followed by logistic regression analysis to determine the relationship between drinking water treatment and the incidence of diarrhea in children under five.

\section{RESULTS}

Tabel 1. Characteristics of respondents, drinking water treatment

\begin{tabular}{lc}
\hline Variable & $\mathrm{n}(\%)$ \\
\hline $\begin{array}{l}\text { Age (mother, years), means } \pm \text { SD } \\
\text { Education level }\end{array} \quad 29,18 \pm 6,81$ \\
$\quad$ Junior high school & \\
$\quad \leq$ Junior high school & $35(33,65)$ \\
Employment status & $69(66,35)$ \\
$\quad$ Employed & \\
$\quad$ Unemployed & $27(25,96)$ \\
Sex (children) & $77(74,04)$ \\
$\quad$ Male & \\
$\quad$ Female & $41(39,42)$ \\
Birth weight & $63(60,58)$ \\
$\quad$ Low birth weight & \\
$\quad$ Normal birth weight & $25(24.04)$ \\
Age (children, months) mean \pm SD & $79(75,96)$ \\
Diarrhea & $30,2 \pm 14,0$ \\
$\quad$ Yes & \\
$\quad$ No & $67(64,42)$ \\
Drinking water treatment & $37(35,58)$ \\
$\quad$ Good & \\
$\quad$ Poor & $21(20,19)$ \\
Jumlah & $83(79,81)$ \\
\hline
\end{tabular}


Table 1 shows that the average age of respondents is still young is 29 years, $66.35 \%$ of respondents with low education are below junior high school, $74.04 \%$ of respondents do not work, the average (median) age of children under five is 30 months, as many as $60.58 \%$ of toddlers are female, $75.9 \%$ of children under five are born with normal weight, as many as $64.42 \%$ of children under five have had diarrhea in the last three months, most of the $79.81 \%$ of respondents have poor family drinking water treatment.

Tabel 2. The frequency of mother's habits in cultivating the correct way in mother's parenting

\begin{tabular}{lr}
\hline Drinking water treatment & $\mathrm{n}(\%)$ \\
\hline Does the mother boil drinking water before consumption & \\
$\quad$ Always & $43(41,35)$ \\
$\quad$ Sometimes & $31(29,81)$ \\
$\quad$ Never & $30(28,85)$ \\
Drinking water is stored in a tightly closed container & \\
$\quad$ Always & $36(34,62)$ \\
$\quad$ Sometimes & $25(24,04)$ \\
$\quad$ Never & $43(41,35)$ \\
Wash drinking containers with soap and running water after three days or & \\
when the water runs out & \\
$\quad$ Always & $38(36,54)$ \\
$\quad$ Sometimes & $21(20,19)$ \\
$\quad$ Never & $45(43,27)$ \\
Distance of clean water sources and sources of pollution (mean \pm SD) & $6,03 \pm 5,5$
\end{tabular}

Table 2 shows the respondents who always boiled drinking water before consumption were $41.35 \%$, most of the $43(41.35 \%)$ respondents never kept drinking water in a closed container, as many as $43.27 \%$ never washed drinking water containers with an average the distance between the source of clean water and the source of pollution is $6.03 \pm 5.5$.

Tabel 3. Bivariate analysis of the relationship between characteristics, birth weight and drinking water treatment with the incidence of diarrhea in children under five

\begin{tabular}{|c|c|c|c|c|}
\hline Variable & $\begin{array}{l}\text { Diarrhea (+) } \\
\text { n }(\%)\end{array}$ & $\begin{array}{l}\text { Diarrhea (-) } \\
\text { n (\%) }\end{array}$ & P Value & \\
\hline Employment status & & & \multirow{3}{*}{0,78} & $29,46 \pm 6,84$ \\
\hline Employed & $18(66,67)$ & $9(33,33)$ & & \\
\hline Unemployed & $49(63,64)$ & $28(36,36)$ & & \\
\hline Education level & & & \multirow{3}{*}{0,84} & \\
\hline$>$ Junior high school & $23(65,71)$ & $12(34,29)$ & & \\
\hline$\leq$ Junior high school & $44(63,77)$ & $25(36,23)$ & & \\
\hline Sex (Children) & & & & \\
\hline Male & $28(68,29)$ & $13(31,71)$ & \multirow[t]{2}{*}{0,51} & \\
\hline Female & $39(61,90)$ & $24(38,10)$ & & \\
\hline Birth weight & & & \multirow{3}{*}{0,06} & $8(68,29)$ \\
\hline Low & $20(80,00)$ & $5(20,00)$ & & \\
\hline Normal & $47(59,49)$ & $32(40,51)$ & & \\
\hline \multicolumn{4}{|l|}{$\begin{array}{l}\text { Drinking water } \\
\text { treatment }\end{array}$} & \\
\hline Good & $35(56,45)$ & $27(43,55)$ & \multirow[t]{2}{*}{0,03} & \\
\hline Poor & $32(76,19)$ & $10(23,81)$ & & \\
\hline
\end{tabular}

Table 3 presents the results of the bivariate analysis between the incidence of diarrhea in children under five with several variables. Based on the bivariate test, the variable drinking water treatment a lack of relationship with the incidence of diarrhea in children under five with a $\mathrm{P}$ value $=0.03$.

\section{DISCUSSION}

This study was successful in proving that there was a significant relationship between poorly managed drinking water and the incidence of diarrhea. This is in line with the research conducted by Dewi Ratnawati et al. (2006) in Kulon Progo Yogyakarta with a case control research design, showing that 
the use of clean water facilities that do not meet sanitation requirements will increase the risk of 1.310 times greater for toddlers to suffer from acute diarrhea. compared to the use of clean water facilities that meet the requirements but it is not statistically significant.

The results of the research by Septian Bumulo (2012) show that respondents whose clean water supply facilities do not meet the requirements and do not have diarrhea, namely as much as $52.7 \%$, in addition, $29.4 \%$ are obtained that the water supply facilities meet the requirements but cause diarrhea. This is because some respondents still hold water for drinking and cooking in an open container. . The data on the availability of clean water that is sought in this study is water for drinking and cooking purposes. The results of the descriptive analysis of drinking and cooking water sources in the two groups were different. The results of interviews with research respondents also revealed that $76.19 \%$ of the diarrhea group who did not boil water first before cooking it was used for cooking. This is different in the normal group, the proportion of respondents who boiled water first until it boiled was $43.55 \%$ of respondents who did not boil water until it boiled still contained bacteria that could cause children to experience disease infections. Most of the distance from the water source is also close to the septic tank / waste storage in the diarrhea group, so the risk of the water source being contaminated with bacteria / germs is greater.

Cooking drinking water in this study is a family behavior in processing drinking water that is mostly practiced by the general public. Based on the results of this study, it shows that most respondents (59.62\%) boiled water before consumption and 42 respondents $(40.38 \%)$ did not boil their drinking water before consumption.

The results of the chi square analysis stated that $76.19 \%$ of respondents who did not boil the water to a boil had toddlers who had diarrhea, while $56.45 \%$ of respondents who boiled the water boiled. Based on the bivariate results, it shows that there is a significant relationship with the parenting style of mothers who boil water with the incidence of diarrhea in toddlers with a value of $p=0.039$.

According to the Director General of P2PL (2008), water for drinking must be treated first and the water container must be clean and closed. Water that is not managed with household drinking water management standards can cause disease. One form of household drinking water treatment that is simple and often used is cooking. Cooking is a process of killing disease-causing microorganisms by heating $(\mathrm{MOH}, 2008)$. Clean water is water that is used for daily purposes which will become drinking water after cooking it first. As a limitation, clean water is water that meets the requirements for a drinking water supply system. The requirements in question are requirements in terms of water quality which include physical, chemical, biological and radiological quality, so that if consumed it does not cause side effects (Kep.Men.Kes RI No. 416 / Menkes / Per / IX / 1990). Clean water facilities is a building and its tools and equipment that provide and distribute the water to the community. Clean water facilities must meet health requirements so that they are not contaminated so that good water quality can be obtained in accordance with health standards.

Boiling water is the best way to purify water at home. In order for the purification process to be more effective, eat the water and let it boil for between 5-10 minutes. It is intended that all germs, spores, cysts and eggs die so that the water is sterile (Chandra, 2007).

\section{CONCLUSION}

The way of managing family drinking water is still not significantly related to the incidence of diarrhea in children under five. So it is necessary to make it a habit to manage water use in the family properly, such as boiling water before it is consumed by the family so that it can reduce the risk of disease.

\section{ACKNOWLEDGMENTS}

We would like to thank the head of Mataram City Health Office, the Head of Cakranegara Public Health and all respondent who have participated in this study.

\section{CONFLICTS OF INTEREST}

The author declares that they have no conflict of interest

\section{REFERENCES}

Bumulo S. (2012). The relationship between clean water supply facilities and the type of family latrine with the incidence of diarrhea in children under five in the Piloloda Community Health Center in 2012 (thesis). Gorontalo State University |Published by Public Health Journal 
Nasution.( 2006). Improving Health Status through Health Education and Implementation of a Healthy Lifestyle. Medan

World Health Organization (WHO). 2004. Global Water Supply and Sanitation Assesment. World Health Organization, Geneva

Kemenkes. (2011). Diarrhea Situation in Indonesia (Bulletin). Jakarta: Health Data and Information Window Bulletin No. 2

Decree of the Minister of Health of the Republic of Indonesia Number 907 / Menkes / SK / VII / 2002 concerning Requirements and Supervision of Drinking Water Quality.

Minister of Health Regulation No. 416 of 1990 concerning Requirements and Monitoring of Water Quality

Nugraheni. (2012). Relationship of Basic Personal Hygiene Sanitation Facility Conditions with Diarrhea Incidence in North Semarang District. Thesis thesis, Journal of Public Health Vol. 1 No. 2 of 2012, 922-930

Rosa, Syaefty Dewi. (2011). The Relationship between Household Drinking Water Treatment and Mother's Healthy Behavior and Diarrhea Incidence in Toddlers at Cipayung Public Health Center, Depok City. Thesis: University of Indonesia.

Directorate General of Disease Control and Environmental Health (P2PL) Ministry of Health of the Republic of Indonesia Year (2008). Guidelines for Implementation of Sanitation Hygiene for Drinking Water Depots]. Jakarta

Depkes RI.( 2008). Guidelines for the Management of Health Promotion in Achieving Clean and Healthy Behavior (PHBS). Jakarta: Depkes RI.

Depkes RI (2005) . Handbook of P2 Diarrhea Program Implementation. Jakarta: Depkes RI

Depkes RI (2007). Brief Information on Disease Control and Environmental Health. Jakarta: Directorate General of Disease Control and Environmental Health.

Decree of the Minister of Health of the Republic of Indonesia Number 416 / Menkes / Per / IX / 1990 concerning Requirements for Clean Water Quality.

Chandra, Budiman, (2007). Introduction to Environmental Health. Jakarta. Medical Book Publishers EGC 